\title{
Antioxidant potential of various solvent extract from Morus alba fruits and its major polyphenols composition
}

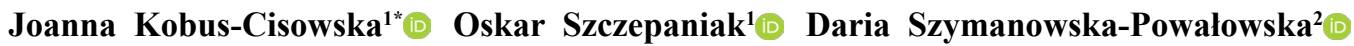 \\ Justyna Piechocka ${ }^{1}$ Piotr Szulc $^{3}$ (D) Marcin Dziedziński ${ }^{1}$ (D)
}

\author{
${ }^{1}$ Department of Gastronomy Science and Functional Foods, Poznan University of Life Sciences, 60637, Poznań, Poland. E-mail: joanna.kobus@up.poznan.pl. \\ ${ }^{*}$ Corresponding author. \\ ${ }^{2}$ Department of Biotechnology and Food Microbiology, Poznan University of Life Sciences, Poznan, Poland. \\ ${ }^{3}$ Department of Agronomy, Poznan University of Life Sciences, Poznan, Poland.
}

ABSTRACT: Extraction conditions are an important factor in the process of obtaining bioactive compounds from plant matrix. These compounds differ structurally. Structures of phyto-compounds and their interactions with other food ingredient are not fully known, while these two aspects should play a significant role in extrahents choice and determination of extraction process conditions. Mulberry (Morus alba) is a plant growing in Asia, which fruits are rich in bioactive ingredients and high anti-oxidative potential. In our study we analyzed mulberry fruits extracts differing in the extra hent applied: acetone, methanol, ethanol and water. All tested extracts possessed rich polyphenolic composition and radical scavenging ability. The significant differences among the extracts in phenolic acids and flavonoids compositions were noticed, where the highest values were observed for acetone extract. The extrahent applied affects the antioxidative profile of tested samples, as well. The highest scavenging activity against ABTS was observed for acetone and ethanol extracts, while the poorest activity had water extract. Similar results were provided for ferrous ion reducing test and Fe chlating activity (acetone $>$ ethanol $>$ methanol $>$ water). These results are helpful when selecting solvents with appropriate bioactive compounds compositions and high phytochemical profiles to be used as ingredients in supplements, as well as in functional foods.

Key words: Morus alba, antioxidants, phenolic acids, flavonoids.

Potencial antioxidante de vários extratos de frutos de Morus alba e de sua composição majoritária de polifenóis

RESUMO: As condições de extração são um fator importante no processo de obtenção de compostos bioativos da matriz vegetal. Estes compostos diferem-se estruturalmente. As estruturas de fito conjugações e suas interações com outros ingredientes alimentares não são totalmente conhecidas, enquanto esses dois aspectos devem desempenhar um papel significativo na escolha de extrações e na determinação das condições do processo de extração. A amoreira (Morus alba) é uma planta que cresce na Asia, cujos frutos são ricos em ingredientes bioativos e com alto potencial antioxidante. Em nosso estudo, analisamos extratos de frutos de amoreira diferindo no extraente aplicado: acetona, metanol, etanol e água. Todos os extratos testa dos possuíam composição polifenólica rica e capacidade de eliminação de radicais livres. As diferenças significativas entre os extratos em composições de ácidos fenólicos e flavonóides foram observadas, em que os maiores valores foram observados para o extrato de acetona. O extraente aplicado afeta também o perfil antioxidante das amostras testadas. A maior atividade de eliminação contra o ABTS foi observada para a acetone e etanol extração, enquanto a atividade mais pobre tinha água. Resultados semelhantes foram fornecidos para teste de redução de ions ferrosos e atividade de aglutinação de Fe (acetona $>$ etanol $>$ metanol $>$ água). Estes resultados são úteis na seleção de solventes com composições apropriadas de compostos bioativos e altos perfis fitoquímicos para serem usados como ingredientes em suplementos, bem como em alimentos funcionais.

Palavras-chave: Morus alba, antioxidants, ácidosfenólicos, flavonóids.

\section{INTRODUCTION}

The mulberry (genus Morus, family Moracea) has a long history of domestication and grows across an extensive range of soil, geographical and climatic conditions. In most Asian countries, mulberry trees are an economically important plant in the sericulture industry and have traditionally been used for feeding silkworms, Bombyxmori L. (PÉREZGREGORIO et al., 2011; ZHAO et al., 2019).

In recent years, mulberry has become more popular in the world because of its antioxidant effects. More mulberry fruit and its extract are used in food products and pharmaceuticals. Several investigations have revealed the presence of many bioactive components in all Morus varieties, such as carotenoids, flavonoids, phenolic acids, alkaloids, vitamins, fats (mainly linoleic acid, palmitic acid, and oleic acid), sugars, and minerals. It is known that many bioactivities, such as antioxidant effects, are linked to the presence of phenolics in mulberry fruit. However, this content also differs between different kinds of mulberry trees. For example, there is a much higher anthocyanin content in black mulberry fruits 
(Morus nigra) than in red (Morus rubra) and white fruits (Morus alba) (HE et al., 2019; ZHANG et al., 2018). Both total phenolic and total flavonoid content in Morus nigra are also significantly higher than in Morus rubra and Morus alba and the content of ascorbic acid in Morus alba is the highest. However, all varieties of mulberries are a rich source of phenolics (JIN et al., 2017; ZHAO et al., 2019).

Many polyphenols extracted from the plant can be used as natural antioxidants. Many studies have shown the content and species of phenolic compounds to have close correlations with antioxidant capacity (KHALIFA et al., 2019; KOBUS-CISOWSKA et al., 2019a; et al., 2019b). Phenolic compounds in natural plants included polyphenols with either monomeric or complex structures. Simple ones contained phenolic acids, phenylpropanoids and flavonoids. Complicated ones included lignin, macromolecular pigment and tannins. The most effective phenolic compounds demonstrated in mulberry fruits are flavonols (JIN et al., 2017; KUTLU et al., 2011; MEMON et al., 2010). The study of flavonoids from mulberry leafs and their antioxidant effects has also shown their scavenging effects on superoxide radicals (ZOU et al., 2012). Mulberry extract contains large quantities of rutin which is considered to be a major phenolic compound.

The extraction method is an important stage in the process of bioactive ingredients obtaining from the plant matrix. These ingredients differ in structure. Their chemical structure and interactions with other nutrients are not completely explained, what impedes the choice of the proper extrahent and extraction process conditions. Polyphenols which are the prevalent group of phytocompounds of mulberry fruits, are susceptible to oxidation (JIN et al., 2017; KOBUS-CISOWSKA et al., 2019b). High temperature and alkali conditions cause degradation of them. Therefore, sample preparation to the extraction process, the parameters of this process and extrahent choice can be accounted to the most vital questions, which should be considered.

Studies into the Morus species have investigated phenolic acids content, flavonoids, antioxidant activity and many other areas. However, differences in chemical composition dependent on extraction solutions have not yet been investigated in M.alba fruit. Therefore, the aim of this study was to compare aqueous, methanol, ethanol and acetone extracts of Morus alba fruit in terms of chemical composition and antioxidant activity.

\section{MATERIALS AND METHODS}

\section{Materials}

Mulberry fruits were delivered from Zhejiang Province, People Republic of China. Air drying in the absence of $\mathrm{SO}_{2}$ was applied at temperature $65 \pm 1{ }^{\circ} \mathrm{C}$ to obtain dry mass at minimum level of $94 \%$. Raw material was characterized including determination of the basic chemical ingredients as dry mass $84,23 \pm 1,09 \%$, ash $15,21 \pm 0,76 \%$, fatty acids $1,67 \pm 0,12 \%$, protein $4,31+0,08 \%$. Mulberry fruits were ground into pieces in an laboratory mill (Retsch, Germany) to a mesh size 0.05-0.15 mm. All solvents were of analytical grade unless otherwise specified. Flavonol and phenolic acid standards were of HPLC-grade purity and purchased from SigmaAldrich (St Louis, MO, USA). Other chemicals, such as 2,2-diphenyl-1-picrylhydrazyl• (DPPH•), 6-hydroxy-2,5,7,8-tetramethylchroman-2-carboxylic acid (Trolox), 2,2'-azinobis-(3-ethylbenzothiazoline6-sulfonic acid) (ABTS), were also purchased from Sigma-Aldrich (St. Louis, MO, USA).

\section{Methods}

Mulberry fruits were extracted with different solvents: deionized water (MW), aqueous ethanol (ethanol: water, 75:25 v/v) termed ethanol extract (ME), aqueous methanol (methanol: water, 75:25 v/v) termed methanol extract (MM), aqueous acetone (acetone: water, 75:25 v/v) termed acetone extract (MA) at atmospheric pressure under the following conditions: $4 \mathrm{~g}$ ground product was extracted with $40 \mathrm{ml}$ : deionized water at $95{ }^{\circ} \mathrm{C}$, aqueous acetone at $40{ }^{\circ} \mathrm{C}$, aqueous ethanol and aqueous methanol at $20^{\circ} \mathrm{C}$. Extraction was performed in a shaking water bath for 15-minat first. The extract was filtered through Whatman No. 4 paper and rinsed with $50 \mathrm{ml}$ of the second part of the solvent. Residue extraction was repeated, applying the same conditions three times. The three solvent filtrates were combined and evaporated under a vacuum (ethanol, methanol, acetone); residual water was removed by freeze drying to produce dry extract. The aqueous solvent mixture indexes were calculated from equation $\left(\mathrm{I}_{\mathrm{A}} / 100 \times \mathrm{P}_{\mathrm{A}}\right)+\left(\mathrm{I}_{\mathrm{B}} / 100 \times \mathrm{P}_{\mathrm{B}}\right)$ where $\mathrm{I}_{\mathrm{A}}$ and $\mathrm{I}_{\mathrm{B}}$ are polarity index of solvents $A$ and $B$, respectively, and $\mathrm{P}_{A}$ and $\mathrm{P}_{\mathrm{B}}$ are percentage of solvents $\mathrm{A}$ and $\mathrm{B}$, respectively, in the solvent mixture.

Then, the prepared crude extracts were stored in a dry, dark and cool place until they were analyzed.

Separation and identification of extracted flavonoids from mulberry were determined following the method described in previous study(KOBUSCISOWSKAet al., 2019c). Detection was performed using Agilent UPLC (Agilent, CA, USA) with column NovaPak C18 (Waters, US, 3,9 x $150 \mathrm{~mm}$; $5 \mu \mathrm{m})$ a UV-Vis detector at $\lambda=370 \mathrm{~nm}$. Identification was based on the retention times and characteristic of 
UV spectra. The gradient elution was applied, where the mobile phase consisted of two solvents: $0.3 \%$ aqueous formic acid solution (A) and acetonitrile (B). Gradient schedule started with $15 \%$ and ended with $25 \%$ eluent $\mathrm{B}$ at analysis time 40 minutes. Flow rate was $1.0 \mathrm{~mL} / \mathrm{min}$. Selected flavonoids were identified with use of the comparison of their retention times $\left(\mathrm{t}_{\mathrm{r}}\right)$ and peak surfaces( $S$ ) with $t_{r}$ and $S$ of the standards. All analyses were performed in triplicate.

The phenolic acid analysis was conducted using an Agilent UPLC (Agilent, CA, USA) equipped with a vacuum degasser and a Bin Pump Infinity DAD 1290 detector according to the method described previously (KOBUS-CISOWSKA; et al., 2019c). A Nova-Pak C18 (Waters, USA) reversed-phase column $(3.9 \times 150 \mathrm{~mm}, 5-\mu \mathrm{m}$ particle size $)$ was used for separation. UV detection was performed at 270 $\mathrm{nm}$. Phenolic acids were identified using standards dissolved in methanol by applying a method described by KOBUS-CISOWSKA et al.(2019c). The gradient elution was applied in the following set: water acidified with ortho-phosphoric acid to $\mathrm{pH}$ 2.6 (A), acetonitrile/water $(1: 1 \mathrm{v} / \mathrm{v})(\mathrm{B})$, with flow rate $1 \mathrm{~mL} / \mathrm{min}$. Elution started with $100 \%$ A solution nded with $50 \%$ A at 50 minute of analysis. Detection was conducted at two wavelengths 250 and $320 \mathrm{~nm}$ (UV-VIS detector). Final results were calculated by comparing tr and $\mathrm{A}$ of peaks in chromatograms with tr and A of peaks characteristics for elution of methanolic standards.

Antioxidant activity with ABTS radicals, according to Re et al. (1999), consisted of the reduction of colored radical cation ABTS by the antioxidants present in the tested extracts and spectrophotometric (MetertekSP-830, Taiwan) measurement of changes in the concentration of cation ABTS, after 6 minutes at $30^{\circ} \mathrm{C}$, at a wavelength of $734 \mathrm{~nm}$. The antioxidant capacity was expressed as Trolox equivalent antioxidant capacity (TEAC) in the form of mmol Trolox per $\mathrm{kg}$ sample by means of a dose-response curve for Trolox. Determination of antioxidant capacity with DPPH radicals consisted of the reduction of colored cation DPPH by the antioxidants present in the tested extracts and spectrophotometric (MetertekSP-830, Taiwan) measurement of changes in the concentration of cation $\mathrm{DPPH}$, after 20 minutes at $20{ }^{\circ} \mathrm{C}$, at a wavelength of $517 \mathrm{~nm}$ (AMAROWICZ et al. 2000).

Ferrous ion-chelating effects of the mulberry extracts were estimated according to the method ofAMAROWICZ et al.(2000) by colorimetric measurement $(562 \mathrm{~nm})$ of the amount of $\mathrm{Fe}^{2+}$ which did not chelate with extracts and 3-(2-pyridyl)-5,6bis(4-phenyl-sulfonicacid)-1,2,4-triazine (ferrozine).
The reducing power of the extracts was determined according to the procedure described earlier; (AMAROWICZ et al., 2000). Absorbance was read at $700 \mathrm{~nm}$ using a spectrophotometer (Metertek SP830, Taiwan).

All assays were conducted in triplicates and results expressed as mean \pm SD. One way ANOVA testing was used to analyze statistical differences amongst the various extracts for phenolic compound contents and different antioxidant assays with least significance difference (LSD). The P value less than 0.05 was assumed as a level of significance. Correlations between the content of components and antioxidant attributes were determined by Pearson's correlation coefficients. Additionally, the analysis of the principal components was used (PCA). Statistical analyses were calculated using Statistica 13.3 software (Statsoft, Poland).

\section{RESULTS AND DISCUSSION}

\section{Extraction yield}

The yield of the extraction with water, acetone-water, ethanol-water and mixtures of methanol of soluble components of the white mulberry fruits were estimated (Table 1). Statistically significant higher extraction efficiency was obtained using acetone $(16.17 \%)$ and ethanol $(15.82 \%)$. A lower yield of $13.42 \%$ and $10.11 \%$ was characterized by a methanol and water extracts, respectively.

BRAHMI et al. (2012) compared the extraction yield of Algerian mint. They used different solvents, giving (in descending order): acetone $(75 \%)>$ ethanol $(75 \%)>$ methanol $(75 \%)>$ ethanol $\quad(50 \%)>$ methanol $\quad(50 \%)>$ acetone $(50 \%)>$ methanol $>$ ethanol $>$ acetone. This is in line with our studies. Solvent polarity played a pivotal function in all extraction studies. The net molecular polarities of solvents were measured by their dipole moments (Table 1 for solvent polarities). The separation of components depends on the polarity of both solvent and component. For plant materials, $100 \%$ recovery of individual components might be not achieved since a single solvent may not be selective for a single compound (BINDES et al., 2019). The phenolic compounds in the extract are linked with other biomolecules (e.g., proteins, polysaccharides, terpenes, chlorophyll, lipids and inorganic compounds). Therefore, a solvent has to be suitable for extracting all of them. Extraction of other biomolecules could probably explain the very high percentage yield obtained in the acetone and ethanol extract in this study which was higher than 
Table 1 - Solvent effects on the yield of Morus alba fruits extraction.

\begin{tabular}{lcc}
\hline Extraction solvent & Snyder's solvent polarity index & Extract yield (\% g/g sample) \\
\hline Aqueous & - & $10.11^{\mathrm{a}}$ \\
$75 \%$ acetone $(75: 25 \mathrm{v} / \mathrm{v}$ acetone-water) & 6.3 & $16.17^{\mathrm{c}}$ \\
\hline $75 \%$ ethanol $(75: 25 \mathrm{v} / \mathrm{v}$ ethanol-water) & 6.15 & $15.82^{\mathrm{c}}$ \\
$75 \%$ methanol $(75: 25 \mathrm{v} / \mathrm{v}$ methanol-water $)$ & 7.2 & $13.42^{\mathrm{b}}$ \\
\hline
\end{tabular}

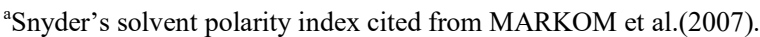

Results are mean values of three determinations \pm standard deviation.

Values sharing the same letter in a column are not significantly different $(\mathrm{P} \leq 0.05)$.

that for methanol and water. The high yield of the extraction using either acetone or ethanol could be feasible due to the ability of these extracts to dissolve endogenous compounds together with phenols. Methanol is reported to be the most suitable solvent in the extraction of polyphenolic compounds from plant tissue (ANOKWORU et al., 2011). Aqueous methanol, due to its polarity, is more effective at extracting polyphenols linked to polar fibrous matrices. In contrast, acetone/water mixtures are more useful for extracting polyphenols from protein matrices (TABART et al., 2007). In general, ethanol or methanol solutions containing some water, particularly those consisting of $40-80 \%$ ethanol or methanol, had greater efficiency in the extraction of polyphenolic compounds compared to water or pure ethanol or methanol.

\section{Flavonoids}

Qualitative and quantitative analyses of five flavonoids contents in mulberry extracts were performed and results are presented in table 2 . Analysis of the composition of the flavonol content of the tested mulberry fruit extracts showed that their qualitative composition was similar, but they were quantitatively different. A significantly higher content of flavonoids was manifested in the acetone extract $(2833 \mu \mathrm{g} / \mathrm{g}$ d.w. $)(\mathrm{p}<0.05)$ and this was five times higher than that of the aqueous extract of $553 \mu \mathrm{g} / \mathrm{g}$ d.w. In all examined extracts the dominant flavonoid was rutin, the contents of which were determined at the level of $2376 \mu \mathrm{g} / \mathrm{g}$ d.w. in MA, $1644 \mu \mathrm{g} / \mathrm{g}$ d.m. in MM, $1255 \mu \mathrm{g} / \mathrm{g}$ d.m.in the ME and $432 \mu \mathrm{g} / \mathrm{g}$ d.m. in MW. Mulberry extracts also showed a high content of quercetin and gallocatechins whose level ranged 32-222 $\mu \mathrm{g} / \mathrm{g}$ d.w. extract.

In the literature, there are numerous research about qualitative and quantitative analysis of flavonoids in mulberry leaves and fruit, which give very different results. ZHANG et al. (2018) reported that the main flavonoids in mulberry fruit were rutin, morin, quercetin and myricetin which is in line with our studies. CHANG et al. (2011) reported that rutin, isoquercetin, morin but also maclurin and resveratol are the main group of flavonoids in Morus which influence the bioactivity of this plant. LI et al. (2017) reported rutin to be the popular phenolic compounds in white mulberry. KATSUBE et al. (2006) reported that the main flavonol glycoside of M. alba was rutin, which is in accordance with our results. The variation of phenolic compounds in the extract depends on many factors, such as the degree of maturity at harvest, genetic differences and environmental conditions during fruit development. JAGTAP \& BAPAT (2013) reported that the content of quercetin, kaempferolandis or hamnetin varied significantly depending on the solvent-methanol and water (on average this was higher in the extracts with methanol). RADOJKOVIC et al. (2012) compared and characterized the phenolic and flavonoid content and antioxidant activities of different extracts of selected Serbian Morus species. Rutin is the predominant flavonoid in these mulberry fruit species (43.5 mg/100 g for M. alba fruit and $72.6 \mathrm{mg} / 100 \mathrm{~g}$ for $M$. nigra fruit). Generally, polyphenols are known as good antioxidants, which may exert influences in different ways, but the literature reports are not consistent, suggesting good and poor relationships between polyphenols and antioxidant activity. Some authors reported a direct correlation between antioxidant activity and total phenolic content (GRAMZA-MICHAŁOWSKA et al., 2018; KOBUSCISOWSKA; et al., 2019a). The antioxidant activity of polyphenols may resulted in a redox properties, which play the role of reducing agents or hydrogenatom donors. Consequently, they can act as chelate 
Table 2 - Total flavonoids content in different extracts of Morus alba fruits obtained with different solvents. Each value is expressed as the means \pm SD $(n=3)$.

\begin{tabular}{|c|c|c|c|c|c|c|c|c|c|c|c|c|}
\hline \multirow{2}{*}{$\begin{array}{l}\text { Component } \\
\text { Epigallocatechin( } \mu \mathrm{g} / \mathrm{g} \text { d.m. })\end{array}$} & \multicolumn{3}{|c|}{---------MW--------- } & \multicolumn{3}{|c|}{--------MA-------- } & \multicolumn{3}{|c|}{---------ME----------- } & \multicolumn{3}{|c|}{---------MM------- } \\
\hline & $25^{\mathrm{b}}$ & \pm & 1 & $66^{\mathrm{a}}$ & \pm & 2 & $23^{b}$ & \pm & 1 & $59^{\mathrm{a}}$ & \pm & 3 \\
\hline Gallocatechin( $\mu \mathrm{g} / \mathrm{g}$ d.m. $)$ & $32^{d}$ & \pm & 2 & $169^{\mathrm{a}}$ & \pm & 8 & $123^{\mathrm{c}}$ & \pm & 5 & $147^{\mathrm{b}}$ & \pm & 6 \\
\hline Kaempferol ( $\mu \mathrm{g} / \mathrm{g}$ d.m.) & nd & & & nd & & & nd & & & nd & & \\
\hline Quercetin ( $\mu \mathrm{g} / \mathrm{g}$ d.m.) & $64^{c}$ & \pm & 2 & $222^{\mathrm{a}}$ & \pm & 5 & $134^{\mathrm{b}}$ & \pm & 3 & $144^{\mathrm{a}}$ & \pm & 7 \\
\hline Rutin ( $\mu \mathrm{g} / \mathrm{g}$ d.m.) & $432^{\mathrm{d}}$ & \pm & 22 & $2376^{\mathrm{a}}$ & \pm & 88 & $1255^{\mathrm{c}}$ & \pm & 66 & $1644^{\mathrm{b}}$ & \pm & 76 \\
\hline Total flavonoids( $\mu \mathrm{g} / \mathrm{g}$ d.m.) & $553^{\mathrm{d}}$ & \pm & 22 & $2833^{\mathrm{a}}$ & \pm & 72 & $1535^{\mathrm{c}}$ & \pm & 67 & $1994^{\mathrm{b}}$ & \pm & 55 \\
\hline
\end{tabular}

Abbreviations: MW-water infusion from Morus alba fruits, MA-acetone-water extract from Morus alba fruits, ME-ethanol extract from Morus alba fruits, MM-methanol extract from Morus alba fruits. Results are mean values of three determinations \pm standard deviation. Values sharing the same letter in a line are not significantly different $(\alpha=0.05)$. nd - not detected.

metal constituents or they can scavenge free radicals (ZHANG et al., 2018).

The presence of flavonoids in the mulberry extracts determined their antioxidant properties in biological systems, as well as in heterogeneous systems of food products. Mulberry extracts could show a high antioxidant potential, due to a significant content of rutin. However, during the evaluation of the antioxidant properties not only the total content is important. The co-existence of other components is also responsible for the antioxidant effect.

\section{Phenolic acid content}

Phenolic acids are reported to be in the main group of phytochemicals responsible for the antioxidant capacity of fruits and vegetables (JIN et al., 2017). So, in our study nine phenolic acids were tentatively identified in mulberry extracts by the standards and published data, which included a group of derivatives of hydroxybenzoic acids and a group of derivatives of hydroxycinnamic acids (Table 3 ). Among the estimated phenolic acids the predominant were ferulic, chlorogenic and protocatechuic acids which occurred at statistically significantly higher levels than the others $(\mathrm{p}<0.05)$. It was reported that the type of solvent used had a significant influence on the content of phenolic acids in the extracts (Table 3 ). In extracts from mulberry leaves ferulic acid, which was the predominant acid, had its highest estimated level in the acetone extract at $1265 \mu \mathrm{g} / \mathrm{g} \mathrm{d.w}$. and its lowest in the aqueous extract $476 \mu \mathrm{g} / \mathrm{g}$ d.w. Chlorogenic acid was observed at the level of $122 \mu \mathrm{g}$ / $g$ d.w. in the aqueous extract to 433 in the ethanol extract. In contrast, protocatechuic acid occurs in the range 106-255 $\mu \mathrm{g} / \mathrm{g}$ d.w in the water extract and in acetone extract, respectively. Among the analyzed phenolic acids the content of gallic acid $(14 \mu \mathrm{g} / \mathrm{g}$ d.w. in MW to $73 \mu \mathrm{g} / \mathrm{g}$ d.w. in MM) was reported to be the smallest. ZADERNOWSKI et al. (2005) researched several small berries grown in Northeastern Poland, including black mulberries. The total content of phenolic acids, identified by GC-MS, ranged from $2845.8 \mathrm{mg} / \mathrm{kg}$ d.w. (black mulberries) to $5418.2 \mathrm{mg} /$ $\mathrm{kg}$ d.w. (blue-berried honeysuckle). Twenty phenolic acids were identified in the berries and $o$-coumaric acid was present only in blueberries and mulberries. A similar qualitative composition was achieved by JIN et al. (2017), who analyzed the polyphenols in mulberry extracts and showed clear peaks indicating the presence of chlorogenic and protocatechuic acids, which is in line with our results. Contrasting results were achieved by RADOJKOVIC et al. (2012). These authors compared different extracts of selected Serbian mulberry fruit species according to phenolic acid profiles, and they did not detect ferulic or sinapic acids. MEMON et al. (2010) identified and quantified eleven phenolic acids and their aldehyde derivatives namely, gallic, protocatechuic, protocatechuic aldehyde, $p$-hydroxybenzoic, vanillic, chlorogenic, syringic, syringaldehyde, $p$-coumaric, ferulic, $m$-coumaric. The phenolic acid profiles varied with the type of species and the matrix (leaves or fruits) analyzed. Chlorgenic acid (24\%) was the abundant phenolic acid in the $M$. albafruits, whereas protocatechuic acid (41\%) was observed in the highest concentration in $M$. nigra fruits.

In summary, all the analyzed mulberry fruit extracts were rich in phenolic acids. The greatest amounts were estimated in the aqueous-acetone extract (2176), then ethanol (2027 $\mu \mathrm{g} / \mathrm{g} \mathrm{d.m.).} \mathrm{It}$ 
Table 3 - HPLC analysis of phenolic acids in different extracts of Morus alba fruits.

\begin{tabular}{|c|c|c|c|c|c|c|c|c|c|c|c|c|}
\hline \multirow{2}{*}{$\begin{array}{l}\text { Component } \\
\text { Caffeic acid ( } \mu \mathrm{g} / \mathrm{g} \text { d.m.) }\end{array}$} & \multicolumn{3}{|c|}{---------MW------- } & \multicolumn{3}{|c|}{-----------MA----------- } & \multicolumn{3}{|c|}{----------ME--------- } & \multicolumn{3}{|c|}{--------MM-------- } \\
\hline & $43^{b}$ & \pm & 3 & $62^{\mathrm{b}}$ & \pm & 3 & $17^{\mathrm{a}}$ & \pm & 2 & $12^{\mathrm{a}}$ & \pm & 1 \\
\hline Chlorogenic acid ( $\mu \mathrm{g} / \mathrm{g}$ d.m.) & $122^{\mathrm{a}}$ & \pm & 7 & $343^{b}$ & \pm & 11 & $433^{c}$ & \pm & 22 & $311^{\mathrm{b}}$ & \pm & 9 \\
\hline Ferulic acid ( $\mu \mathrm{g} / \mathrm{g}$ d.m.) & $476^{\mathrm{a}}$ & \pm & 23 & $1265^{\mathrm{d}}$ & \pm & 52 & $104^{\mathrm{c}}$ & \pm & 66 & $879^{\mathrm{b}}$ & \pm & 33 \\
\hline Gallic acid ( $\mu \mathrm{g} / \mathrm{g}$ d.m.) & $64^{\mathrm{b}}$ & \pm & 1 & $55^{\mathrm{b}}$ & \pm & 1 & $35^{\mathrm{a}}$ & \pm & 2 & $33^{\mathrm{a}}$ & \pm & 2 \\
\hline$O$-coumaric acid ( $\mu \mathrm{g} / \mathrm{g} \mathrm{d}$ d.m.) & $44^{\mathrm{a}}$ & \pm & 2 & $54^{\mathrm{a}}$ & \pm & 1 & $86^{\mathrm{b}}$ & \pm & 6 & $76^{\mathrm{b}}$ & \pm & 8 \\
\hline$P$-coumaric acid ( $\mu \mathrm{g} / \mathrm{g}$ d.m.) & $43^{\mathrm{a}}$ & \pm & 4 & $111^{\mathrm{b}}$ & \pm & 7 & $155^{\mathrm{c}}$ & \pm & 11 & $125^{\mathrm{b}}$ & \pm & 13 \\
\hline P-hydroxybenzoic acid ( $\mu \mathrm{g} / \mathrm{g}$ d.m.) & $24^{\mathrm{a}}$ & \pm & 1 & $48^{\mathrm{b}}$ & \pm & 1 & $58^{\mathrm{b}}$ & \pm & 2 & $36^{\mathrm{a}}$ & \pm & 5 \\
\hline Protokatechic acid ( $\mu \mathrm{g} / \mathrm{g}$ d.m.) & $106^{\mathrm{a}}$ & \pm & 3 & $255^{\mathrm{c}}$ & \pm & 8 & $145^{\mathrm{b}}$ & \pm & 6 & $123^{\mathrm{b}}$ & \pm & 6 \\
\hline Vanillic acid ( $\mu \mathrm{g} / \mathrm{g}$ d.m.) & $43^{\mathrm{a}}$ & \pm & 1 & $53^{\mathrm{a}}$ & \pm & 1 & $54^{\mathrm{a}}$ & \pm & 1 & $76^{\mathrm{a}}$ & \pm & 3 \\
\hline Total phenolic acids ( $\mu \mathrm{g} / \mathrm{g}$ d.m.) & 895 & & & 2176 & & & 2027 & & & 1711 & & \\
\hline
\end{tabular}

Abbreviations: MW-water infusion from Morus alba fruits, MA-acetone-water extract from Morus alba fruits, ME-ethanol extract from Morus alba fruits, MM-methanol extract from Morus alba fruits. Results are mean values of three determinations \pm standard deviation. Values sharing the same letter in a line are not significantly different $(\alpha=0.05)$. nd - not detected.

seemed that the determined phenolic acid contents may affect their antioxidant properties, whose mechanism of action involved the inhibition of the generation of free radicals, their ability to scavenge and increase the catalytic activity of the endogenous enzymes which participate in neutralizing free radicals. In particular, ferulic, chlorogenic and protocatechuic acids, whose presence in the mulberry extracts was reported at the highest level.

\section{Antioxidant activity with radicals: $D P P H \bullet$ and ABTS}

Radical scavenging capacity was tested against two different radicals: DPPH•, a stable colored radical and ABTS and the results are shown in table 4.

All extracts capable of scavenging DPPH• radicals exhibited antioxidant activity in this order: acetone $>$ methanol $>$ ethanol $>$ water. The scavenging activity ranged from 3.55 to $1.33 \mathrm{TE} / \mathrm{g}$ d.m. of extract, with the highest activity being seen in acetone extracts and the lowest in water extracts. Those extracts possessing high antioxidative activity contained the highest amounts of total phenolic compounds. These reports indicated that acetone was a better solvent for extraction of $\mathrm{DPPH} \bullet$ compounds from mulberry. Statistical analysis showed positive correlations between antioxidant effect against $\mathrm{DPPH} \bullet$ and total flavonoids $(\mathrm{r}=0.63)$, rutin $(\mathrm{r}=0.69)$ and ferulic acid $(\mathrm{r}=0.78)$. Our previous reports demonstrated that aqueous acetonic extracts were the most suitable solvent of antioxidant components from Gingko biloba and scavenged radicals to the greatest degree; i.e. 4.89 (green leaves) and $3.37 \mathrm{mM}$ Trolox/g d.m. (yellow leaves) (KOBUS et al., 2009). The same results were obtained by JAGTAP \& BAPAT (2013), who compared anti-oxidative effect against DPPH• of different apple extracts. These authors showed that acetone was the most effective solvent to extract active compounds; second was methanol, then ethanol and the weakest water, the same as in this study.

NATIĆ et al. (2015) studied the effect of the growing location of mulberry for activity against DPPH• radicals. The high activity level of compounds obtained from mulberry was, as in the present study, positively correlated with the content of phenolic acids and flavonoids. ARAMWIT et al. (2010) showed the high antioxidant activity of Morus fruit to be dependent on their color. The authors reported that activity is positively correlated with the content of flavonoids and anthocyanins and the compounds are stable during 24-hour storage of extracts. In our study, the observed differential scavenging activities of the extracts against the $\mathrm{DPPH} \bullet$ system may be due to the presence of different compounds in the extracts. The activity of the studied mulberry extracts could depend on the chemical structure of phenolic compounds and the availability of phenolic hydroxyl groups which have the capacity to donate their electron or hydrogen, thereby forming stable end products. A high rutin content and a positive correlation with rutin leads to the conclusion that rutin is mainly responsible for $\mathrm{DPPH} \bullet$ activity. This fact can be confirmed by the tests by YANG et al. (2008) who 
Table 4 - Chelating and antioxidant activity of mulberry extract with DPPH and ABTS radicals.

\begin{tabular}{|c|c|c|c|c|c|c|c|c|c|c|c|c|}
\hline \multirow{2}{*}{$\begin{array}{l}\text { Component } \\
\text { DPPH mM Trolox/g d.m. }\end{array}$} & \multicolumn{3}{|c|}{-----MW } & \multicolumn{3}{|c|}{ MA } & \multicolumn{3}{|c|}{ ME } & \multicolumn{3}{|c|}{ MM } \\
\hline & $1.33^{\mathrm{c}}$ & \pm & 0.05 & $3.55^{\mathrm{a}}$ & \pm & 0.21 & $2.87^{b}$ & \pm & 0.11 & $3.34^{\mathrm{a}}$ & \pm & 0.26 \\
\hline ABTS mM Trolox/g d.m. & $1.24^{\mathrm{b}}$ & \pm & 0.02 & $1.32^{\mathrm{b}}$ & \pm & 0.05 & $0.69^{\mathrm{a}}$ & \pm & 0.03 & $0.92^{\mathrm{b}}$ & \pm & 0.07 \\
\hline Chelating activity $(\%)$ & $12.66^{\mathrm{c}}$ & \pm & 0.52 & $69.22^{\mathrm{a}}$ & \pm & 3.04 & $56.26^{\mathrm{a}}$ & \pm & 1.03 & $47.87^{\mathrm{b}}$ & \pm & 1.91 \\
\hline
\end{tabular}

Abbreviations are defined in table 2 .Results are mean values of three determinations \pm standard deviation. Values sharing the same letter in a line are not significantly different $(\mathrm{P} \leq 0.05)$.

investigated the antioxidant characteristics of rutin in in vitro environments at $0.05 \mathrm{mg} / \mathrm{ml}$ concentrations. They detected scavenging activity of DPPH• radicals as $90.4 \%$ and this was the highest among different commonly occurring polyphenols.

All extracts from mulberry were tested with $\mathrm{ABTS}^{\bullet+}$. In the $\mathrm{ABTS}^{\bullet+}$ scavenging method, the activity of tested mulberry fruit extracts was expressed as Trolox equivalent, the same as in DPPH• Antioxidant capacity was measured as the ability to prevent $\mathrm{ABTS}^{-+}$or react directly with $\mathrm{ABTS}^{\cdot+}$ which reduces the blue color, thus the scavenging activity can be measured with a spectrophotometer at 734 $\mathrm{nm}$. The reduced $\mathrm{ABTS}^{\circ+}$ activity in this study is presented in table 3 . The highest scavenging activity is in the acetone solvent extract sample, as high as $1.32 \mathrm{TE} / \mathrm{g}$ d.m. of extract, which is quite similar to $1.24 \mathrm{TE} / \mathrm{g} \mathrm{d} . \mathrm{m}$. of extract scavenging capacity in water solvent extracts. In methanol solvent extracts the ability was $0.92 \mathrm{TE} / \mathrm{g}$ d.m. of extract. The lowest scavenging activity appears in ethanol extract: 0.69 TE/g d.m. of extract. After statistical analysis, except for ethanol extract solvent, the antiradical capacity of water, acetone and methanol extract solvents did not show significant differences. Statistical analysis showed positive correlations between antioxidant effect against $\mathrm{ABTS}^{\cdot+}$ and total flavonoids $(\mathrm{r}=0.71)$, quercetin $(\mathrm{r}=0.64)$, gallic acid $(\mathrm{r}=0.77)$ and caffeic acid $(r=0.73)$. In the literature, many reports discussed issues concerning the antioxidant activity of the extracts on the content of phenolic compounds and the results of these studies have been contradictory. While some researchers have found a correlation between the content of individual polyphenols and antioxidant activity, others have reported a lack thereof.

In vitro antioxidant properties of 3 different black mulberry extracts (Morus nigra L.) were investigated by KUTLU et al. (2011). Acidified methanol, acidified water, and non-acidified methanol/water solutions were used to prepare extracts. The antiradical activity was positively correlated with flavonoids, but the researchers did not find any correlation with phenolic acids.

The results of the research presented in this paper showed acetone-water extract to have the highest activity against $\mathrm{DPPH}^{\cdot}$ radical and $\mathrm{ABTS}^{\cdot+}$. The fewest radical $\mathrm{DPPH}^{\cdot}$ scavenged compounds were contained in the aqueous extract and the lowest activity against $\mathrm{ABTS}^{\cdot+}$ was reported in the ethanol extract. Anti-radical activity was affected by both flavonoids(quercetin and itsglycoside-rutin) and some phenolic acids(gallic and coffee).

\section{Chelating activity}

Metal chelating activity was determined on ferrous ion and the results are in table 3. Acetone-water extract demonstrated the greatest chelating activity of ferrous ions $(69.22 \%)$, with ethanol-water extract processing $56.26 \%$ capacity and the methanol extract ( $47.87 \%$ capacity) and water $12.66 \%$ of ferrous. This result suggested that chelating activity in mulberry fruit depends on the solvents used. The degree to which flavonoids can form metal ion complexes depends on their chemical structures. Flavonoids have various chelating ability, as good chelators are naringenin and taxifolin, others showed moderate chelation, e.g. rutin and are several flavonoids with no chelation activity, e.g. hesperetin (ARFAN et al., 2012; MISHRA et al., 2010).

It is known that the number and position of hydroxyl moieties attached to the B-ring are closely correlated with chelating activity. A larger number of hydroxyl substituents corresponded to greater chelating activity. The $o$-diphenol groups at positions 3 ' and 4' on the B-ring as well as the 4-keto and 3-hydroxyl groups or 4-keto and 5-hydroxyl groups on the flavanoid's C-ring are considered to be the sites of metal binding to flavonoid molecules. Some authors also suggested that a double bond between C-2 and C-3 of the C-ring can enhances the flavonoid's capacity to 
chelate ferrous ions. After chelation with metal ions, flavonoids also retain the ability to scavenging free radicals (JIN et al., 2017). This fact may be able to explain why higher concentrations of flavonoids did not result in higher chelating activity. KOBUS et al. (2009) identified the same result in gingko leaves and this research proves that using the same solvent, e.g. water, but increasing the concentration from $400 \mathrm{ppm}$ to $800 \mathrm{ppm}$ did not have any additional effect in terms of metal ion chelation.

An immediate termination of the oxidation reaction is not only the action of antioxidants. This happens in the case of free radicals scavengers that convert free radicals to more stable forms (NIMSE $\&$ PAL, 2015). The second group of compounds with antioxidant activity, known as secondary antioxidants, work via other mechanisms. One of these mechanisms is the chelation of metals, which occur as pro-oxidants. Iron and other transition metals (arsenic, cadmium, copper, chromium, cobalt, nickel, and vanadium) can act as oxidation catalysts. These transition metals have redox activity and can transfer single electrons. Metal chelation of certain compounds-secondary antioxidants-reduces their activity as pro-oxidants, by reducing the redox potential and stabilizing oxidized forms of the metal. Chelating compounds may also sterically hinder formation of the metal hydroperoxide complex (REISCHE et al., 2008). Analysis of the results led us to the conclusion that the best chelating properties were characterized in the acetone extracts of mulberry, which was probably the result of a significant presence of gallocatechin, with 6 hydroxyl groups in their structure, and quercetin that includes 5 hydroxyl groups.

\section{Reducing power}

Figure 1 presents the reducing power of different mulberry extracts. All analyzed extracts were able to reduce ions in a dose-dependent manner and exhibited reducing power in this order: acetone $>$ ethanol $>$ methanol $>$ water. There was no statistical difference between ethanol and methanol extracts. Those extracts with high reducing power (acetone and ethanol) contained the highest amounts of total phenolic compounds. The reducing power for acetone $(0.453 ; 0.765)$, ethanol $(0.444 ; 0.654)$, methanol $(0.329 ; 0.688)$ and water $(0.222 ; 0.459)$ were at lower (200 ppm) and higher ( $900 \mathrm{ppm})$ doses, respectively. These results indicated that acetone was a better solvent for the extraction of reducing Fe ion compounds from mulberry. Statistical analysis showed that there is a positive correlation between the content of flavonoids and the reducing power of extracts $(\mathrm{r}=0.78)$. There was no correlation for the dependencies between the content of phenolic acids and reducing the ability of transition ions. Therefore, the results of statistical analyses led to the assignment to flavonoids of a major role in shaping the reducing activity of mulberry extracts. The experiment of reducing the power of Morus has also been investigated elsewhere. CHANG et al. (2011) studied mulberry twig and root bark and indicated that higher concentrations of phenolic compounds material is linked to a capacity for high reducing power. In a similar experiment, ARABSHAHI-DELOUEE \& UROOJ (2007) came to a similar conclusion. As the concentration of bioactive compounds mostly correlated to reducing power, thus the water extract may contain higher levels of antioxidant compounds than other extractions. JAGTAP \& BAPAT (2013) investigated the reducing power of various apple solvent extracts, and they showed that reducing potential was significantly affected by the solvent used for the extraction in the same order as in this study.

However, AMAROWICZ et al. (2008) reported a contrasting observation. In their studies, the use of methanol and acetone as the extractant did not affect the value of the reducing power. The absorbance of $0.5 \mathrm{mg}$ of methanol and acetone extract of vine leaves was the same, i.e. 0.8.

Different studies have indicated that the electron donation capacity (reflecting the reducing power) of bioactive compounds is associated with antioxidant activity (GÖÇER \& GÜLÇIN, 2011; LEE et al., 2015). Compounds with reducing power indicated that they are electron donors and can reduce the oxidized intermediates of lipid peroxidation processes, so that they can act as primary and secondary antioxidants (REISCHE et al. 2008). It has been reported that reducing power is generally associated with the presence of reductions, which have been shown to exert antioxidant action by breaking the free radical chain via donation of a hydrogen atom (ZHANG, et al., 2018). Acetone extract and alcoholic extract have high levels of reductions which are considered to be total polyphenols.

The results of our analyses have established that all mulberry extracts have the ability to reduce the transition metal ions represented by iron, and this activity was increased with increasing concentration. It was found that reducing power was depended on the solvents which were used to make an extract. Flavonoids had a major role in the reducing activity of mulberry extracts. 


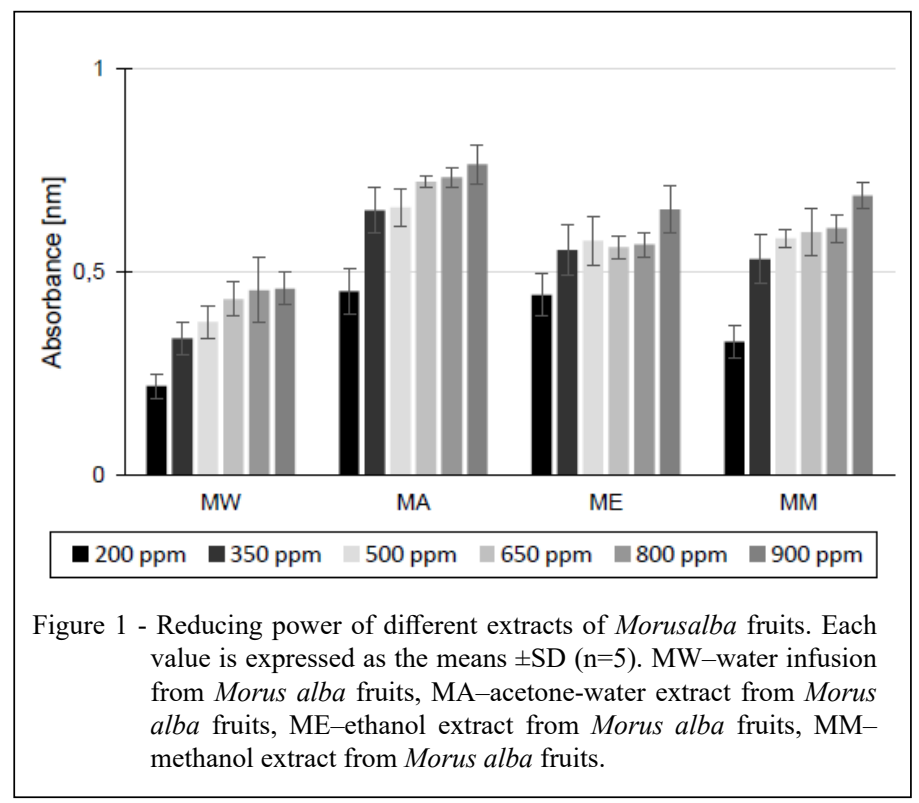

\section{Principal component analysis}

PCA projection (biplot) of results for qualitative analysis of mulberry fruits extracts in set of two first components (PC1 and PC2), responsible for approximately $60 \%$ composition deviation, presented the heterogeneity of tested samples in terms of bioactive ingredients composition and the degree of influence of selected compounds on extracts' characteristic (Figure 2). The stacking of acetone-aqueous, methanolic and ethanolic extract samples at the right part of the figure 2, indicates the higher deviation of these samples in contrary to the

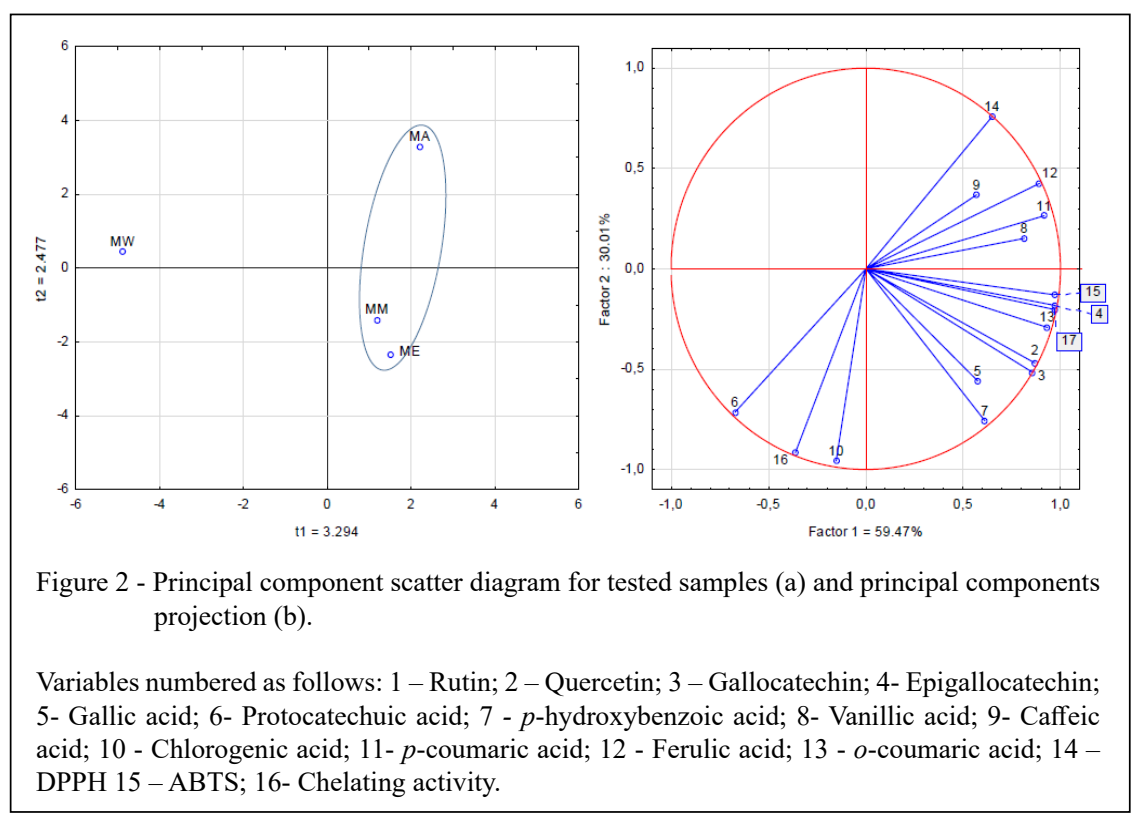

Ciência Rural, v.50, n.1, 2020. 
aqueous extract in terms of the content of analyzed compounds and assayed antioxidative activity.

\section{CONCLUSION}

The data presented in this report demonstrated that extraction method concerning the solvent choice, affects the activity of obtained preparations of Morus alba fruits. It was observed thatacetone-water and ethanol preparation have high flavonol and phenolic acid contents and anti-oxidative activity in different model systems. Conversely, the diversity in extracts composition and their antioxidative activity, leads to final statement that extraction is a good method for bioactive compounds concentration. Mulberry fruits can be a valuable source of a whole range of phytocompounds, which final total antioxidative effect is hard to predict. It is caused by the various activity of tested extracts. Moreover, the study results confirmed that the current knowledge about phytopreparations activity must be still strengthened, due to the possibility of synergic effect induced by phytocompounds mutual interactions.

Study results underlined the nutritive and phytomedicinal potentials of the Morus alba fruit. These results are helpful when selecting solvents with appropriate bioactive compounds compositions and high phytochemical profiles to be used as ingredients in supplements, as well as in functional foods.

\section{ACKNOWLEDGEMENTS}

There was no financial aid for this work.

\section{DECLARATION OF CONFLICT OF INTERESTS}

The authors declare no conflict of interest. The founding sponsors had no role in the design of the study; in the collection, analyses, or interpretation of data; in the writing of the manuscript, and in the decision to publish the results.

\section{AUTHORS' CONTRIBUTIONS}

All authors contributed equally for the conception and writing of the manuscript. All authors critically revised the manuscript and approved of the final version.

\section{REFERENCES}

AMAROWICZ, R.; NACZK, M.; SHAHIDI, F. Antioxidant activity of various fractions of non-tannin phenolics of canola hulls. Journal of Agricultural and Food Chemistry, 2000. v.48, n.7, p.2755-2759. Available from: <https://pubs.acs.org/doi. org/10.1021/jf9911601>. Accessed: May, 9, 2019.
AMAROWICZ, R., et al. Antioxidant and radical scavenging activities of a barley crude extract and its fraction. Czech Journal of Food Sciences, 7 jan. 2008. v.25, n.2, p.73-80. Available from: <http://linkinghub.elsevier.com/retrieve/pii/ S0308814603002784>. Accessed: May, 9, 2019.

ANOKWORU, C. P. et al. Polyphenolic Content and Antioxidant Activity of Hibiscus sabdariffa Calyx. Research Journal of Medicinal Plant, 1 maio. 2011. v.5, n.5, p.557-566. Available from: <http://www.scialert.net/abstract/?doi=rjmp.2011.557.566>. Accessed: May, 9, 2019.

ARABSHAHI-DELOUEE, S.; UROOJ, A. Antioxidant properties of various solvent extracts of mulberry (Morus indica L.) leaves. Food Chemistry, jan. 2007. v.102, n.4, p.1233-1240. Available from: <https://linkinghub.elsevier.com/retrieve/pii/ S0308814606005784>. Accessed: May, 9, 2019.

ARAMWIT, P. et al. The Effect of Sericin from Various Extraction Methods on Cell Viability and Collagen Production. International Journal of Molecular Sciences, 20 maio. 2010. v.11, n.5, p.2200-2211. Available from: <http://www.mdpi.com/14220067/11/5/2200>. Accessed: May, 9, 2019.

ARFAN, M. et al. Antioxidant Activity of Mulberry Fruit Extracts. International Journal of Molecular Sciences, 22 fev. 2012. v.13, n.2, p.2472-2480. Available from: <http://www.ncbi.nlm.nih.gov/ pubmed/22408465>. Accessed: May, 12, 2019.

BINDES, M. M. M. et al. Maximisation of the polyphenols extraction yield from green tea leaves and sequential clarification. Journal of Food Engineering, 1 jan. 2019. v.241, p.97-104. Available from: <https://www.sciencedirect.com/science/article/ abs/pii/S0260877418303376>. Accessed: May, 9, 2019.

BRAHMI, F. et al. The efficacy of phenolics compounds with different polarities as antioxidants from olive leaves depending on seasonal variations. Industrial Crops and Products, 2012. v.38, p.146-152. Available from: <https://www.sciencedirect.com/science/article/abs/ pii/S0926669012000581>. Accessed: May, 9, 2019.

CHANG, L.-W. et al. Antioxidant and antityrosinase activity of mulberry (Morus alba L.) twigs and root bark. Food and Chemical Toxicology, 2011. v.49, n.4, p.785-790. Available from: <https:// www.sciencedirect.com/science/article/pii/S0278691510007039>. Accessed: May, 9, 2019.

GÖÇER, H.; GÜLÇIN, İ. Caffeic acid phenethyl ester (CAPE): correlation of structure and antioxidant properties. International Journal of Food Sciences and Nutrition, 2 dez. 2011. v.62, n.8, p.821-825. Available from: <http://www.tandfonline.com/doi/full/ 10.3109/09637486.2011.585963>. Accessed: May, 12, 2019.

GRAMZA-MICHAŁOWSKA, A. et al. Phytonutrients in Oat (Avena sativa L.) Drink: Effect of Plant Extract on Antiradical Capacity, Nutritional Value and Sensory Characteristics. Polish Journal of Food and Nutrition Sciences, 1 mar. 2018. v.68, n.1, p.63-71. Available from: <http://content.sciendo.com/view/ journals/pjfns/68/1/article-p63.xml>. Accessed: May, 9, 2019.

HE, Y. et al. Protective effect of mulberry crude extract against nonylphenol-induced thyroid disruption by inhibiting the activity of deiodinase in rats. General and Comparative Endocrinology, 1 jan. 2019. v.270, p.90-95. Available from: $\quad<$ https://www.sciencedirect.com/science/article/pii/ S0016648018301928?via\%3Dihub>. Accessed: May, 9, 2019. 
JAGTAP, U. B.; BAPAT, V. A. Green synthesis of silver nanoparticles using Artocarpus heterophyllus Lam. seed extract and its antibacterial activity. Industrial Crops and Products, 1 abr. 2013. v.46, p.132-137. Available from: <https://www. sciencedirect.com/science/article/pii/S0926669013000460>. Accessed: May, 12, 2019.

JIN, Q. et al. Identification of polyphenols in mulberry (genus Morus) cultivars by liquid chromatography with time-of-flight mass spectrometer. Journal of Food Composition and Analysis, 1 out. 2017. v.63, p.55-64.: Available from: <https://www.sciencedirect.com/ science/article/pii/S088915751730159X>. Accessed: May, 9, 2019.

KATSUBE, T. et al. Antioxidant flavonol glycosides in mulberry (Morus alba L.) leaves isolated based on LDL antioxidant activity. Food Chemistry, 1 jul. 2006. v.97, n.1, p.25-31. Available from: $\quad<$ https://www.sciencedirect.com/science/article/pii/ S0308814605002712>. Accessed: May, 12, 2019.

KHALIFA, I. et al. Anti-glycation and anti-hardening effects of microencapsulated mulberry polyphenols in high-protein-sugar ball models through binding with some glycation sites of whey proteins. International Journal of Biological Macromolecules, 15 fev. 2019. v.123, p.10-19. Available from: <https://www. sciencedirect.com/science/article/pii/S0141813018351067>. Accessed: May, 9, 2019.

KOBUS-CISOWSKA, J.; SZYMANOWSKA, D.; SZCZEPANIAK, O.; et al. Composition and In Vitro Effects of Cultivars of Humulus lupulus L. Hops on Cholinesterase Activity and Microbial Growth Nutrients, 2019 a. v.11, n.6, p.1377. Available from: <https://www.mdpi.com/2072-6643/11/6/1377>. Accessed: May, 9, 2019.

MACIEJEWSKA, P.; et al. In vitro screening for acetylcholinesterase and butyrylcholinesterase inhibition and antimicrobial activity of chia seeds (Salvia hispanica). Electronic Journal of Biotechnology, jan. 2019b. v.37, p.1-10. Available from: <https://linkinghub.elsevier.com/retrieve/pii/ S0717345818300411>. Accessed: May, 9, 2019.

SZCZEPANIAK, O. M.; et al. Composition

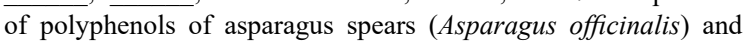
their antioxidant potential. Ciência Rural, 8 abr. 2019c. v.49, n.4, p.e20180863. Available from: <http://www.scielo.br/scielo. php?script $=$ sci arttext\&pid=S0103-84782019000400751\&lng=en \&tlng=en>. Accessed: May, 9, 2019.

KOBUS, J. et al. Phenolic compounds and antioxidant activity of extracts of Ginkgo leaves. European Journal of Lipid Science and Technology, nov. 2009. v.111, n.11, p.1150-1160. Available from: <http://doi.wiley.com/10.1002/ejlt.200800299>. Accessed: May, 9, 2019.

KUTLU, T. et al. Antioxidant properties of different extracts of black mulberry (Morus nigra L.). Turkish Journal of Biology, 2011. v.35, n.1, p.103-110. Available from: <https://journals.tubitak.gov.tr/ biology/abstract.htm?id=11460>. Accessed: May, 9, 2019.

LEE, C. Y. et al. Effect of electron donating groups on polyphenolbased antioxidant dendrimers. Biochimie, abr. 2015. v.111, p.125134. Available from: <https://linkinghub.elsevier.com/retrieve/pii/ S0300908415000280>. Accessed: May, 9, 2019.

LI, F. et al. The novel contributors of anti-diabetic potential in mulberry polyphenols revealed by UHPLC-HR-ESI-TOF-MS/
MS. Food Research International, 1 out. 2017. v.100, p.873-884. Available from: <https://www.sciencedirect.com/science/article/ pii/S0963996917303046?via\%3Dihub>. Accessed: May, 12, 2019.

MARKOM, M. et al. Extraction of hydrolysable tannins from Phyllanthus niruri Linn.: Effects of solvents and extraction methods. Separation and Purification Technology, 1 jan. 2007. v.52, n.3, p.487-496. Available from: <https://www. sciencedirect.com/science/article/pii/S1383586606001961>. Accessed: May, 122019.

MEMON, A. A. et al. Phenolic acids profiling and antioxidant potential of mulberry (Morus laevigata W., Morus nigra L., Morus alba L.) leaves and fruits grown in Pakistan. Polish Journal of Food and Nutrition Sciences, 2010. v.60, n.1, p.25-32. Available from: <http://agro.icm.edu.pl/agro/element/ bwmeta1.element.agro-70198bea-e960-47bd-9de9d821124cb5 2b;jsessionid=A89CD4B02F369A9DB29D2A3D792C0A02>. Accessed: Nov. 7, 2019.

MISHRA, N. et al. Study on antioxidant activity of common dry fruits. Food and Chemical Toxicology, 1 dez. 2010. v.48, n.12, p.3316-3320. Available from: <https://www. sciencedirect.com/science/article/pii/S0278691510005399>. Accessed: May, 12, 2019.

NATIĆ, M. M. et al. Analysis and characterisation of phytochemicals in mulberry (Morus alba L.) fruits grown in Vojvodina, North Serbia. Food Chemistry, 15 mar. 2015. v.171, p.128-136. Available from: $<\mathrm{https}: / / \mathrm{www}$.sciencedirect.com/science/article/pii/ S0308814614013260>. Accessed: May, 12, 2019.

NIMSE, S. B.; PAL, D. Free radicals, natural antioxidants, and their reaction mechanisms. Rsc Advances, 2015. v.5, n.35, p. 27986-28006.

PÉREZ-GREGORIO, M. R. et al. Influence of alcoholic fermentation process on antioxidant activity and phenolic levels from mulberries (Morus nigra L.). LWT - Food Science and Technology, 1 out. 2011. v.44, n.8, p.1793-1801. Available from: <https://www.sciencedirect.com/science/article/pii/ S0023643811000922>. Accessed: May, 9, 2019.

RADOJKOVIC, M. et al. Free radical scavenging activity, total phenolic and flavonoid contents of mulberry (Morus spp. L., Moraceae) extracts. Hemijska industrija, 2012. v.66, n.4, p.547-552. Available from: <http://www.doiserbia.nb.rs/Article. aspx?ID=0367-598X1200002R $>$. Accessed: May, 9, 2019.

REISCHE, D. W.; et al. Antioxidants and Their Mechanisms of Action . In: AKOH, C. C.; MIN, D. B. (Org.). Food Lipids,. Chemistry, Nutrition and Biotechnology. Thirs edit ed. Boca Raton: CRC Press, 2008, p.409-434. Available from: $<$ https://www.taylorfrancis.com/books/9781315151854/ chapters/10.1201/9781315151854-30>. Accessed: May, 9, 2019.

TABART, J. et al. Optimisation of extraction of phenolics and antioxidants from black currant leaves and buds and of stability during storage. Food Chemistry, 1 jan. 2007. v.105, n.3, p.1268 1275. Available from: <https://www.sciencedirect.com/science/ article/pii/S0308814607002348>. Accessed: May, 12, 2019.

YANG, Jianxiong; GUO, J.; YUAN, J. In vitro antioxidant properties of rutin. LWT - Food Science and Technology, 1 jul. 2008. v.41, n.6, p.1060-1066. Available from: <https://www. 
sciencedirect.com/science/article/pii/S0023643807002307>. Accessed: May, 12, 2019.

ZADERNOWSKI, R.; NACZK, Marian; NESTEROWICZ, J. Phenolic Acid Profiles in Some Small Berries. Journal of Agricultural and Food Chemistry, mar. 2005. v.53, n.6, p.2118-2124. Available from: <https://pubs.acs.org/doi/10.1021/ jf040411p >. Accessed: May, 9, 2019.

ZHANG, D.-Y. et al. Evaluation of the alkaloid, polyphenols, and antioxidant contents of various mulberry cultivars from different planting areas in eastern China. Industrial Crops and Products, 15 out. 2018. v.122, p.298-307. Available from: <https://www.
sciencedirect.com/science/article/pii/S0926669018304849>. Accessed: May, 9, 2019.

ZHAO, S. et al. Molecular characterization of anthocyanin and betulinic acid biosynthesis in red and white mulberry fruits using high-throughput sequencing. Food Chemistry, 1 maio. 2019. v.279, p.364-372. Available from: <https://www.sciencedirect.com/ science/article/pii/S030881461832048X>. Accessed: May, 9, 2019.

ZOU, Y. et al. Phenolics and Antioxidant Activity of Mulberry Leaves Depend on Cultivar and Harvest Month in Southern China. International Journal of Molecular Sciences, 5 dez. 2012. v.13, n.12, p.16544-16553. Available from: <http://www.mdpi. com/1422-0067/13/12/16544>. Accessed: Jul. 27, 2019. 